\title{
TEACHING CREATION PRESENTATIONS SKILLS WITH THE USE OF INQUIRY-BASED EDUCATION
}

Michala ǨrIIZŽOV $\boldsymbol{A}^{*}$, Jihočeská univerzita v Českých Budějovicích

Přijato: 16. 2. 2015 / Akceptováno: 25. 5. 2015

Typ článku: Výzkum

DOI: $10.5507 /$ jtie.2015.005

Abstract: The paper deals with the perception of teaching creation presentations and presentation skills at the University. Summarizes the results of the survey focused on teaching presentations and understanding quality of presentations depending on the education. The survey indicates that teaching is mostly focused on using the program for creating presentations (mostly MS PowerPoint) and setting the rules of presentation. In this paper we discuss the use of Inquiry-based learning to create an idea about preparing presentations. It is introduced education proposal including a discussion of the advantages and disadvantages of this approach.

Key words: teaching presentations, rules of presentations, Inquiry-based education, questionnaire survey.

\section{VÝUKA TVORBY PREZENTACÍ A PREZENTAČNÍCH DOVEDNOSTÍ S VYUŽITÍM BADATELSKY ORIENTOVANÉ VÝUKY}

Resumé: Př́spěvek se zabývá vnímáním výuky tvorby prezentací a prezentačních dovedností na školách studenty vysokých škol. Shrnuje výsledky dotazníkového šetreni zaměreného na výuku prezentací a chápání kvality prezentací v závislosti na výuce. Z šetření vyplývá, že výuka je převážně orientována na ovládání programu na tvorbu prezentací (nejčastěji MS PowerPointu) a nastavení pravidel tvorby prezentací. Vpřispěvku diskutujeme využití Badatelsky orientované výuky $k$ vytvořeni predstavy žáků o prípravě prezentací. Je zde predstaven návrh výuky včetně diskuze výhod a nevýhod tohoto př́stupu. Naznačuje možné využití individuálního badatelského postupu k získání vlastní zkušenosti v oblasti prezentací a stanovení pravidel a zásad prezentací.

Klíčová slova: výuka prezentací, pravidla tvorby prezentací, badatelsky orientovaná výuka, dotazníkové šetření.

*Autor pro korespondenci: krizovam@pf.jcu.cz 


\section{1 Úvod}

$\mathrm{S}$ prezentacemi $\mathrm{v}$ různých formách se $\mathrm{v}$ dnešní době setkávají žáci a učitelé nejen $v$ běžném životě, ale především ve školním prostředí. $Z$ pohledu učitelů jsou již řadu let prezentace používány jako materiál doplňující výuku, za účelem podpořit proces učení žáků. [1] V této oblasti byly realizovány četné výzkumy zaměřující se na vzdělávací efekt prezentací. [2][3] Prezentace jsou zkoumány z pohledu množství informací, které mohou žákům předat a významu $\mathrm{v}$ jejich vzdělávacím procesu. Současně však vnímáme nedostatky $\mathrm{v}$ samotné kvalitě těchto materiálů. $\mathrm{V}$ rámci různých projektů podporujících zapojení ICT do výuky jsou vytvářeny digitální materiály, mimo jiné i prezentace v prostředí MS PowerPoint, jejichž kvalita značně pokulhává. Není myšlena pouze kvalita obsahu, ale také zpracování materiálu. Předpokládáme, že právě tyto výukové prezentace působí na žáky jako vzor, jakési první setkání s prezentací a jejím předvedením a to by nemělo být negativní. Je třeba se i tímto hlediskem zabývat.

\section{Výuka prezentací}

Další poměrně zanedbávaná oblast se týká samotného způsobu výuky tvorby prezentací a prezentačních dovedností. Tato probíhá v současné době od prvního stupně základních škol až po vysokoškolské vzdělávání. Primárně spadá do předmětu informatika a jeho alternativ. Setkáváme se však s případy, kdy vyučující seznamují žáky s pravidly tvorby prezentací i v jiných předmětech. Většinou je tomu tak proto, že požadují prezentace jako výstup samostatných prací žáků $\mathrm{v}$ daném předmětu. $\mathrm{V}$ rámci informatiky vnímáme $\mathrm{v}$ současné době dva odlišné př́stupy $\mathrm{k}$ výuce prezentací. Řada učitelů, především na středních školách, předpokládá, že žáci touto výukou již prošli a tudíž jí není třeba věnovat drahocenný čas, stačí př́ímo ověřit získané dovednosti $\mathrm{v}$ této oblasti. Mohou se pak ze strany žáků setkat $\mathrm{s}$ nepochopením principu prezentace a nedodržováním pravidel prezentací. Druhý př́stup může být reakcí na stále opakující se nedostatky v žákovských prezentacích a jejich projevu. Tito učitelé zavádějí tvorbu prezentací velice důsledně a často již na prvním stupni základních škol. Je možné, že více pocitují tlak společnosti na rozvoj klíčových kompetencí žáků, na rozvoj schopnosti prezentovat sám sebe a své názory, tř́́dit a zpracovávat množství dostupných informací potřebných pro uplatnění se ve společnosti. [4]

\section{3 Šetření v oblasti výuky prezentací}

V rámci rozsáhlejšího výzkumu, zaměřeného na kvalitu žákovských prezentací, jsme vytvořili dotazníkové šetření. Toto vycházelo z potřeby zmapovat současný stav výuky prezentací na základních a středních školách. Byly sestaveny 2 bloky otázek zaměřených na definování kvality prezentací a na poslední zkušenost $\mathrm{s}$ jejich výukou. Respondenti z $95 \%$ zmiňovali výuku na střední škole. Smyslem šetření bylo zjistit, jakou mají respondenti představu o kvalitní prezentaci a jaké vlastnosti by jí prriřadili. Zároveň bylo zjišt’ováno, zda si soubor těchto vlastností vytvořili při výuce a jakým způsobem daná výuka probíhala. Respondenty byli studenti vysokých škol převážně Jihočeského kraje. 


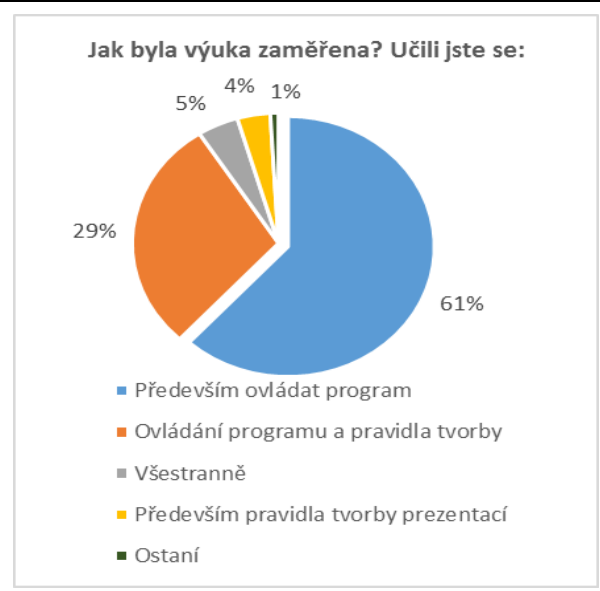

Graf 1 Zaměreni výuky prezentací na SS̆

Uvedené výsledky byly zpracovány u vybrané skupiny respondentů, která zahrnovala 156 studentů vysokých škol (především Jihočeské univerzity) např́č ročníky bakalářských a magisterských oborů (věk 19-26 let).

Autoři si uvědomují subjektivitu vnímání kvality prezentací a obtížnost jejího definování, at' už se jedná o volbu grafického zpracování prezentace (např. kvưli odlišnému vnímání barev) nebo o způsob výběru informací a jejich uspořádání v prezentaci (např. využití odlišných logických struktur). $Z$ tohoto důvodu byly použity otevřené i uzavřené otázky (výčtové či škálové). Otevřených otázek bylo použito především pro zjištění vlastního názoru bez podsouvání názoru autorů.

Šetření potvrdilo, že i přes možnost volné odpovědi, je definování kvalitní prezentace obtížné. Respondenti měli tendenci odpovídat obecnými pojmy, které by bylo třeba podrobněji doptávat v osobním rozhovoru. Přesto uvádíme nejčastěji zmíněná hesla:

\begin{tabular}{|l|l|}
\hline Stručná & $45 \%$ \\
\hline Zajímavá & $28 \%$ \\
\hline Přehledná & $28 \%$ \\
\hline Dobře prezentovaná & $8 \%$ \\
\hline Jednoduchá & $8 \%$ \\
\hline Podle pravidel & $7 \%$ \\
\hline Zábavná & $4 \%$ \\
\hline Pochopitelná & $4 \%$ \\
\hline
\end{tabular}

Tabulka 1 Vlastnosti kvalitni prezentace

Dále uvádíme stručný souhrn výsledků, zaměřených na absolvovanou výuku prezentací na středních školách.

Ze znázorněného grafu vyplývá, že $61 \%$ absolvovalo výuku zaměřenou převážně na ovládání prezentačního softwaru. Zjištění koresponduje s analýzou vybraných učebnic 
pro základní a střední školy, které primárně popisují právě použivání programu na tvorbu prezentací. [5][6]

$45 \%$ respondentů uvedlo, že jim vyučující v průběhu výuky předvedl vzorovou prezentaci, tedy měli možnost vidět tuto prezentaci včetně ústního projevu. $35 \%$ tuto vzorovou prezentaci spolu $\mathrm{s}$ vyučujícím pouze vytvářelo. Ve zbývajících případech během výuky vzorová prezentace nebyla představena. Tyto hodnoty ukazují na upřednostňování tvorby elektronické prezentace na úkor ukázky a nácviku ústního projevu.

Z výsledků šetření uvedených v Grafu 2 dále zjištujeme, že $49 \%$ žáků, kteří absolvovali výuku zaměřenou na ovládání software, bylo zároveň v rámci výuky hodnoceno za odevzdání a prezentování vytvořené závěrečné prezentace. $Z$ uvedených hodnot by se dalo vyvodit, že po těchto žácích učitelé požadovali dovednosti, na které se nezaměřili při výuce.

Podrobněji jsme se dotazovali, jaké oblasti učitel konkrétně v prezentacích hodnotil. Z odpovědí vyplývá, že vyučujícím spíše záleží na využití nástrojů programu, variantu Určitě ano vybralo 89 \% respondentů, na grafickém zpracování prezentace (Určitě ano $76 \%$ ), na správnosti informací uvedených v prezentaci (Určitě ano $74 \%$ ), na logické struktuře prezentace a návaznosti informací (Určitě ano $70 \%$ ), čitelnosti textu

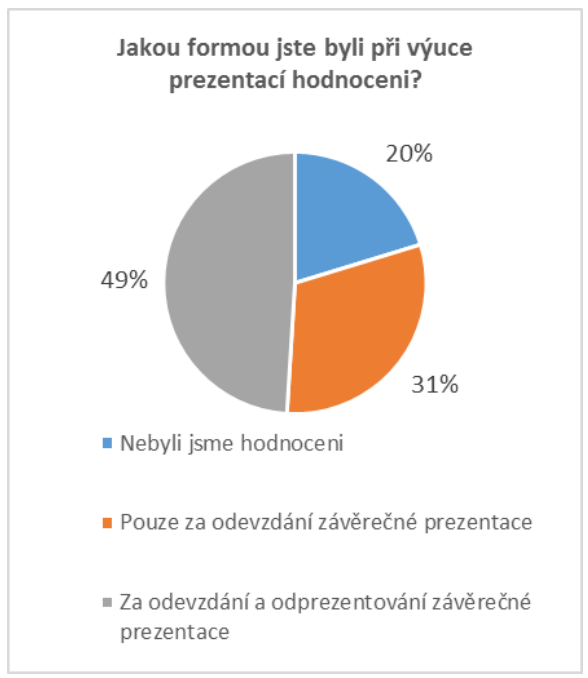

Graf 2 Zaměreni hodnoceni prezentací na SŠ

a viditelnosti objektů v prezentaci (Určitě ano $58 \%$, Spiše ano $22 \%$ ). V př́ípadě vystupování před publikem a prezentování informací volilo $52 \%$ respondentů možnost Spišse ano a $29 \%$ Určitě ano. Naopak negativně se vyjadřovali o hodnocení dodržení časového limitu prezentace, dodržení autorských práv a citování zdrojů informací a dodržení typografických pravidel. Zaměření hodnocení opět ukazuje na elektronickou část prezentace. Překvapením byly negativní odpovědi u uvádění zdrojů informací. Otázkou zůstává, do jaké míry byli respondenti se způsobem hodnocení seznamováni.

Graf 3 znázorňuje další možný důvod, proč se učitelé zaměřjí na zmíněné oblasti. 
Témata, jejichž výuku respondenti absolvovali, na první pohled korespondují s hodnotícími kritérii. Výjimku tvoří tvorba osnovy prezentace. Podle autorů by měla

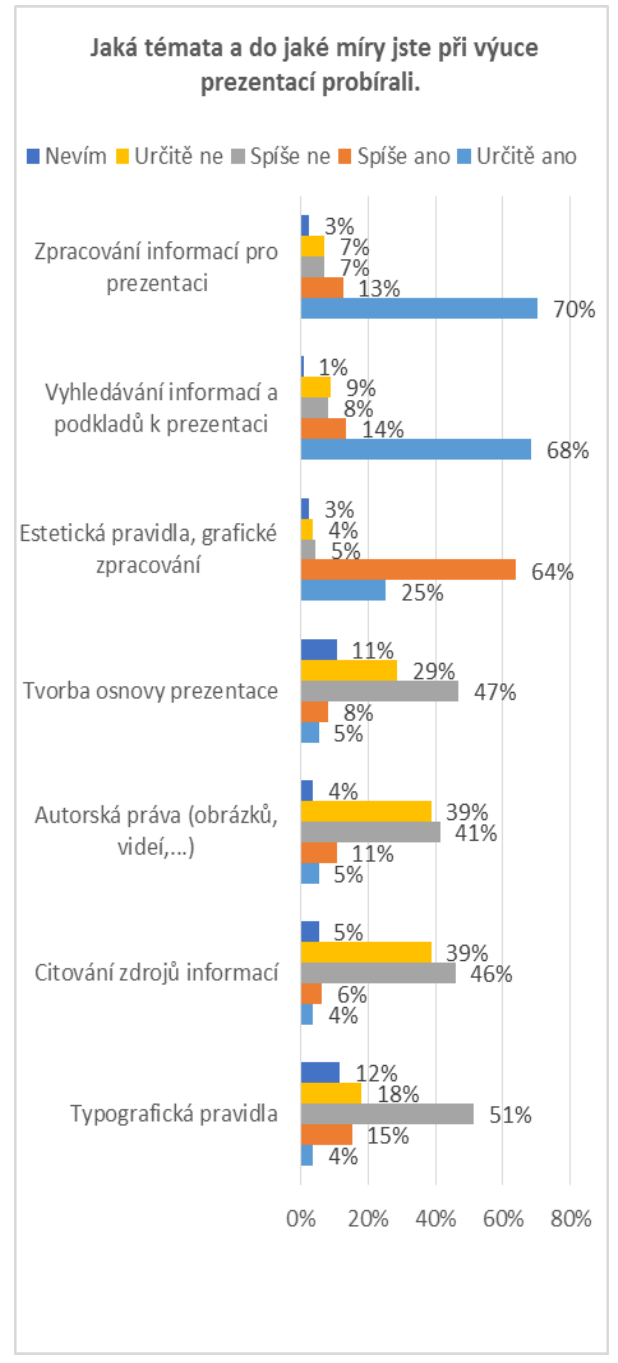

Graf 3 Přehled okruhů výuky prezentací na SŠ

osnova souviset s logickou strukturou prezentace. Chápeme ji jako rozbor zpracovávaného tématu a návrh posloupnosti informací ve výsledné prezentaci (např. formou myšlenkové mapy). Z př̀edchozího vyplývá, že tato oblast byla velice často hodnocena $v$ prezentacích dotazovaných, ačkoliv její výuku si nepřipouštějí. 
Můžeme diskutovat, zda respondenti heslo osnova chápou stejným způsobem, či jim spíše neevokuje obsah prezentace. Toto by opět bylo vhodné ověřit rozhovorem.

Vybrané oblasti byly pouze orientační a respondenti měli možnost $\mathrm{v}$ následující otázce doplnit př́padná chybějící témata. Musíme konstatovat, že nikdo této možnosti nevyužil.

Závěrem shrňme postoj respondentů $\mathrm{k}$ absolvované výuce. 64 \% dotazovaných má pocit, že výuka byla nedostatečná a byli nuceni si chybějící informace samostatně dostudovat. Objevily se i názory, o důležitosti tématu tvorby prezentací a nedostatečné pozornosti, která je jí na školách věnována. Konkrétně byla zmíněna absence výuky estetického cítění, výuky ústního projevu, výuky možností oživení a zatraktivnění prezentací.

Aktuálnost tématu potvrzuje i fakt, že $98 \%$ dotazovaných tvoří prezentace alespoň jednou za půl roku, z toho $20 \%$ alespoň jednou týdně.

\section{Badatelsky orientované vyučování (BOV)}

Současným trendem stále zůstává zavádění nových a efektivněǰš́ch výukových metod do vzdělávacího procesu. Jedním z poměrně nových př́stupů je badatelsky orientované vyučování (BOV). Pokud bychom měli tento př́istup definovat, narazíme v odborné literatuře na různé popisy především zahraničních autorů, $\mathrm{z}$ jejichž

Jako př́klad uvádíme jednu $\mathrm{z}$ definic pojmu bádání (inquiry), na kterém je BOV postavena podle Linna a Bella: in [ 7] (str. 130)

"Inquiry je cílevědomý proces formulování problémů, kritického experimentování, posuzování alternativ, plánování zkoumání a ověřování, vyvozování závěrů, vyhledávání informací, vytváření modelů studovaných dějů, rozpravy s ostatními a formování koherentních argumentů.“

Jiné zdroje popisují tento př́stup $\mathrm{k}$ výuce prrírodních věd jako holistický, pedocentricky orientovaný. Žáci se při něm stávají vědci, potvrzují či vyvracejí hypotézy, zpracovávají získaná data a vyvozují z nich závěry, tak jak bychom to očekávali od skutečného výzkumu. [8][9]

Rozpory ohledně definování BOV se vyskytují i z pohledu jeho zavádění učitelem. BOV můžeme obecně a velmi zkráceně popsat jako postup získávání informací podobající se vědeckému výzkumu.

Jistou orientaci poskytuje Eastwell in [7] (str. 132)

- potvrzující bádání - otázka i postup jsou studentům poskytnuty, výsledky jsou známy, jde o to je vlastní praxí ověřit

- strukturované bádání - otázku i možný postup sděluje učitel, studenti na základě formulují vysvětlení studovaného jevu

- nasměrované bádání - učitel dává výzkumnou otázku, studenti vytvářejí metodický postup a realizují jej

- otevřené bádání - studenti si kladou otázku, promýšlejí postup, provádějí výzkum a formulují výsledky

Jak popisuje ve svém článku Činčera, i v České Republice probíhají snahy o realizaci BOV do výuky př́rodních věd na školách. Jeho zavádění však podle Papáčka limitují nedostatečné kompetence učitelů. Přesto jsou realizovány projekty ve výuce matematiky [10], prŕrodopisu [11], chemie [3] a dalších. 


\section{Zavedení BOV do výuky prezentací}

Naší snahou bylo zavedení BOV do výuky informatiky, konkrétně výuky tvorby prezentací. Pilotní pokus byl realizován v kurzu určeném pro kombinované studium na vysoké škole. Studenti tohoto kurzu často postrádali jakoukoli osobní zkušenost s tvorbou prezentací.

\begin{tabular}{|c|c|}
\hline Text má být v odrážkách & $77 \%$ \\
\hline $\begin{array}{c}\text { Informace v prezentaci by na sebe měly } \\
\text { navazovat }\end{array}$ & $73 \%$ \\
\hline Barva textu má být v kontrastu s barvou pozadí & $68 \%$ \\
\hline Text má být v krátkých větách & $67 \%$ \\
\hline $\begin{array}{l}\text { Prezentaci komentujeme spatra (bez čtení } \\
\text { poznámek nebo textu v prezentaci) }\end{array}$ & $40 \%$ \\
\hline V prezentaci dodržujeme typografická pravidla & $30 \%$ \\
\hline $\begin{array}{l}\text { Je nutné zohledňovat autorská práva při použití } \\
\text { obrázků stažených z internetu }\end{array}$ & $14 \%$ \\
\hline $\begin{array}{l}\text { V prezentaci je možné použít jakékoliv obrázky } \\
\text { stažené z internetu }\end{array}$ & $13 \%$ \\
\hline $\begin{array}{l}\text { V prezentaci předvádíme znalost ovládání } \\
\text { programu (použít animací, různých přechodů } \\
\text { snímků) }\end{array}$ & $10 \%$ \\
\hline $\begin{array}{c}\text { Nadpisy odlišujeme podtržením, kurzívou a } \\
\text { odlišnou barvou }\end{array}$ & $10 \%$ \\
\hline Na začátku tvorby prezentace si vytvoříme Obsah & $8 \%$ \\
\hline $\begin{array}{c}\text { K prezentaci si vytvoříme písemný komentář pro } \\
\text { prezentování }\end{array}$ & $5 \%$ \\
\hline Text v prezentaci může být libovolně dlouhý & $5 \%$ \\
\hline $\begin{array}{c}\text { Nemáme žádná omezení ohledně barvy textu a } \\
\text { pozadí }\end{array}$ & $4 \%$ \\
\hline $\begin{array}{l}\text { Text musí být velký minimálně } 30 \text { bodů a } \\
\text { maximálně } 35 \text { bodů }\end{array}$ & $4 \%$ \\
\hline $\begin{array}{c}\text { Komentář k prezentaci můžeme celý číst z } \\
\text { poznámek }\end{array}$ & $1 \%$ \\
\hline
\end{tabular}

Tabulka 2 Nejčastěji zmiňovaná pravidla v rámci výuky

Při výběru BOV jsme vycházeli z potřeby změny současné výuky, která nebyla př́liš efektivní. $\mathrm{Z}$ důvodu omezené časové dotace byla $\mathrm{v}$ předchozí výuce vybrána forma frontální výuky za pomocí metody výkladu, především v případě stanovení pravidel pro tvorbu prezentací, doporučení pro prezentování a následné demonstrace tvorby 
vzorové prezentace. [12] Při druhém setkání pak studenti prezentovali své závěrečné práce. Tato struktura kurzu nebyla dostačující a nevyhovovala potřebám studentů.

Největší problém během kurzu představovalo stanovení jednoznačných pravidel tvorby prezentací a jejich osvojení studenty. I přes důrazné upozorňování na množství textu v prezentaci, jeho čitelnost a další pravidla, docházelo u studentů $\mathrm{k}$ jejich častému zanedbání. Také opět zmiňujeme subjektivnost vnímání vlastností prezentací. Toto je možné pozorovat především v oblasti grafického zpracování prezentací. Různé barevné kombinace použité v dokumentu nebo uspořádání objektů na snímku vnímáme často odlišně jedinec od jedince a také v různých situacích. Soubor pravidel a poučení ohledně vzhledu prezentace pak vytváŕí každý učitel sám za sebe. Další ze stejně problematických oblastí se jeví např́klad posloupnost informací v prezentaci. Oblast určení základních pravidel prezentace jsme proto stanovili pro realizování strukturovaného bádání studentů. Věříme, že tím spíše přiblížíme pravidla jejich vlastnímu vnímání, ovšem za podmínky, že zásadní pravidla nezůstanou opomenuta.

Podklady pro vznik BOV výuky částečně vycházeli $\mathrm{z}$ dotazníkového šetření. Respondenti zde byli dotazováni na pravidla tvorby prezentací probíraná ve výuce prezentací. Opět jim byly nabídnuty okruhy pravidel s možností doplnění dalších neuvedených. Možnost doplnit seznam pravidel o vlastní nikdo nevyužil.

V Tabulce 2 předkládáme přehled zmíněných pravidel spolu s četností jejich zastoupení $\mathrm{v}$ rámci odpovědí.

V dotazníku byly záměrně zmíněny i protiřečící si varianty pravidel. Tyto varianty často odpovídají oblastem, kde si žáci často nejsou jisti správnou variantou. Jedná se o délku textu, častá chyba vkládání dlouhých odstavcủ textu,

dále tendence použivání tiššných poznámek ke čtení proslovu a také čtení obsahu samotné prezentace. Po rozboru této otázky byl seznam

pravidel použitých ve výuce rozšířen s použitím odborných zdrojů, viz Tabulka 3 níže.

Při př́ípravě BOV jsme vycházeli z předchozí výuky, kdy byl zjištěn účinek osobní zkušenosti na kvalitu studentských prací. Studenti se $\mathrm{v}$ rámci představování vlastních prací, dokázali poučit z chyb kolegů (zjištěno z rozhovorů se studenty). Inspirovali jsme se tímto zjištěním pro realizaci BOV založené na zkušenosti s porušováním základních pravidel tvorby prezentací.

\section{Návrh BOV výuky na stanovení základních pravidel tvorby prezentací}

Výsledný postup navržené BOV je následující:

1. Studenti jsou požádáni o slovní popis vlastní představy kvalitní prezentace Zjištujeme jejich představu o prezentacích před samotnou výukou.

2. Studenti jsou seznámeni $\mathrm{s}$ informačními zdroji, kde mohou nalézt relevantní informace z oblasti plánování struktury prezentací, tvorby jejich elektronické podoby, přednesu atd.

3. Vyučující předkládá studentům vzorovou prezentaci obsahující nejčastěji vyskytující se chyby. Úkolem studentů je nedostatky najít a zároveň určit možnost jejich nápravy.

Badatelská část spočívá $\mathrm{v}$ předpokladu nalezení chyby $\mathrm{v}$ prezentaci. Tuto mohou studenti odhalit bud' vlastní intuicí nebo estetickým cítěním, nebo za použití nápovědy doporučeného zdroje. $\mathrm{V}$ obou př́padech musí zjistit, jak je možné tuto chybu napravit. 
Následuje výčet uvedených chyb:

\begin{tabular}{|c|}
\hline Textové chyby \\
\hline $\begin{array}{l}\text { - } \quad \text { velké množství textu na snímku } \\
\text { - } \quad \text { nedostatečná velikost textu } \\
\text { - } \quad \text { neodlišení nadpisů od ostatního textu } \\
\text { - } \quad \text { typografické a gramatické chyby }\end{array}$ \\
\hline Grafické chyby \\
\hline $\begin{array}{ll}\text { - } & \text { nepřehlednost textu na snímku } \\
\text { - } & \text { nevhodný kontrast barev pozadí a textu }\end{array}$ \\
\hline $\begin{array}{l}\text { - } \quad \text { nevhodně zvolené grafické objekty doplňující text } \\
\text { - nečitelné grafické objekty (velikostí, nepřehledností), } \\
\text { nevhodně umístěné popisky objektů } \\
\text { - } \quad \text { nevhodné použití animací, přechodů snímků a časování }\end{array}$ \\
\hline Logické chyby \\
\hline $\begin{array}{l}\text { - } \quad \text { nevhodné řazení snímků } \\
\text { - } \quad \text { nevhodně vytvořený Obsah prezentace } \\
\text { - } \quad \text { chybějící informace o autorovi, citace a zdroje informací } \\
\text { - } \quad \text { chybné propojení popisu snímku a informací na něm } \\
\text { - } \quad \text { chedených } \\
\text { - } \quad \text { obsah prezí popisky grafických objektů } \\
\text { - nesouvisející s tématem }\end{array}$ \\
\hline
\end{tabular}

Tabulka 3 Přehled nejčastějšich chyb v prezentacich

Výsledky zkoumání prezentace zapisují studenti do pracovních listů pro potřeby následné společné diskuse.

4. Studenti ve skupinách zkoumají prezentaci a za pomoci informačních zdrojů vyhledávají chyby. Skupiny přestavují možnost studentů diskutovat nad nalezenými nedostatky.

5. Zjišsěné poznatky studenti diskutují s vyučujícím.

6. Ze společné diskuse je stanoven soubor pravidel, která by prezentace měla splňovat.

7. Společně (nebo ve skupinách) je provedena korekce prezentace do správné podoby.

8. Výuka je uzavřena závěrečnou diskusí nad definicí kvalitní prezentace. Studenti si eventuálně upravují svou předchozí představu.

Cílem této výuky je společné stanovení zásad pro tvorbu elektronické prezentace a vytvoření názorné představy, jak nevhodné zpracování prezentace vypadá.

Samožrejmě nezapomínáme ani na projev prezentujícího, př́íprava této části bude probíhat $\mathrm{v}$ rámci dalšího výzkumu. Bylo nutné nejdříve vyzkoušet časovou náročnost první části výuky pro stanovení dalších možností jejího rozšiřrení a zjistit přijetí výukové metody studenty kombinovaného studia, kteří se často pohybují mezi 30 až 50 lety. 


\section{Výstupy pilotní výuky}

$80 \%$ studentů pilotní skupiny nemělo předchozí osobní zkušenost s tvorbou prezentací. Představu o kvalitní prezentaci stanovili ve většině prrípadů z vnímání výukových prezentací v průběhu předchozího studia.

Z pilotní výuky vyplynulo, že studenti měli před začátkem výuky pouze obecné představy o vlastnostech kvalitní prezentace. V průběhu zkoumání prezentace častěji hledali pomoc vodborných zdrojích s následnou nápravou chyb, než $\mathrm{s}$ jejich odhalováním. Chyby pro ně byly poměrně lehce čitelné. V doporučených zdrojích se setkávali i s odlišnými doporučenými postupy, $\mathrm{v}$ těchto př́padech žádali radu vyučujícího. Při rozhovorech s jednotlivci bylo zjištěno, že někteří studenti nejdřive přistupovali khodnocení prezentace ostýchavě, nejčastěji kvůli absenci zkušeností s prezentacemi. Většina se však shodla na atraktivnosti metody hodnocení prezentace. U některých studentů spočívala její atraktivita $v$ prrirozené tendenci kritizovat. Jiní studenti se shodli na názoru, že pro ně bylo jednodušší nalézat chyby, než v úvodu stanovit, jak by měla prezentace správně vypadat.

Hlavní př́nos vidíme v komunikaci se studenty a jejich vlastní aktivitě během výuky. Další pozitivum vidíme v možnosti diskutovat nalezené chyby se studenty, při čemž jsou okamžitě odstraňovány dohady o správnosti jejich představ ohledně obsahu a tvorby prezentace. Pravidla stanovená během výuky dále vycházejí z konkrétních prŕikladů, studenti tak mají jasnou představu, jak ukázaná chyba vypadá, a sami by si měli uvědomovat, že je opravdu chybou.

V nejbližší době bude následovat analýza samostatných prací studentů z pilotní výuky. Bude zjišt'ováno, zda se studenti odhalených chyb vyvarovali, či je stále opakují.

Autoři zvažovali zapojení více druhů vzorových prezentací do BOV výuky naráz a rozdělení chyb mezi jednotlivé dokumenty. Prezentace by se odlišovaly tématem a účelem, za kterým byly vytvořeny. Domníváme se, že tyto parametry vytváří odlišný přistup k hodnocení prezentace. Po pilotní výuce se potřeba této úpravy ještě prohloubila. Studenti se právě na účel tvorby prezentace často dotazovali.

V rámci výzkumu je plánováno i zavedení tohoto modelu $\mathrm{BOV}$ do výuky na vybraných středních školách a jeho rozšíření o další výukové bloky.

\section{Závěr}

Z dotazníkového šetření vyplývá, že výuka na středních školách se zaměřuje především na tvorbu elektronických prezentačních dokumentů a možnosti ovládání softwaru. Ústní prezentace je často opomíjena. V tomto směru také samotní respondenti projevili nespokojenost $\mathrm{s}$ výukou prezentací. Bylo zjištěno, že pro konkrétnější analýzu výuky a zároveň i chápání prezentací je vhodnější využít metody kvalitativního výzkumu.

Pilotní výuka prezentací s využitím BOV je postavena na chybné vzorové prezentaci s negativními vlastnostmi. Jejich odhalování a z nich následné vyvození pravidel tvorby prezentace se studentům jevilo jednodušší, než stanovení pravidel bez předchozí zkušenosti. V rámci dalšího výzkumu budou realizovány úpravy vzorové prezentace ke zvýšení obtížnosti nalezení chyb. Obdobná výuka bude připravena i pro nižší stupně škol. 


\section{Literatura}

Trková, L. (2010). Úroveň a četnost uživání PowerPointových prezentací na SŠ (výsledky průzkumu). Vyplňto.cz. [online]. [cit. 2015-1-19].

Dostupné z: http://www.vyplnto.cz/realizovane-pruzkumy/uroven-a-cetnost-uzi/.

Bartch, R. A. \& Cobern, K. M. (2003). Effectiveness of PowerPoint presentations in lectures. Computers [online]. vol. 41, issue 1, s. 77-86.

[cit. 2015-1-19] DOI: 10.1016/S0360-1315(03)00027-7. Dostupné z:

http://linkinghub.elsevier.com/retrieve/pii/S0360131503000277

Urbanová, K. (2012). Efektivita zařazování PowerPointových prezentací do výuky obecné chemie. In: Scientia in educatione [online]. [cit. 2015-1-19]. Dostupné z: http://www.scied.cz/index.php/scied/article/view/28

Bělecký, Z. (2007). Klićcové kompetence v základním vzdělávání. 1. vyd. V Praze: Výzkumný ústav pedagogický.

Kovářová, L. (2009). Informatika pro základni školy. Vyd. 2. Kralice na Hané: Computer Media, 3 sv. 88, 88, 88 s.

Navrátil, P. (2009) S počítačem nejen k maturitě. 7. vyd. Kralice na Hané: Computer Media.

Stuchlíková, I. (2010). O badatelsky orientovaném vyučování. In Papáček (ed.): Didaktika biologie České republice 2010 a badatelsky orientované vyučování. DiBi 2010. Sborník př́spěvků semináre, [online]. 25. a 26. března 2010, s. 129-135, Jihočeská univerzita, České Budějovice. ISBN 978-80-7394-210-6 145-162

Činčera, J. (2014). Význam nezávislých expertních center pro šíření badatelsky orientované výuky v České Republice. In: Scientia in educatione [online]. [cit. 2015-220]. Dostupné z: http://www.scied.cz/index.php/scied/article/viewFile/88/81

Papáček, M. (2010). Limity a šance zavádění badatelsky orientovaného vyučování prírodopisu a biologie v České republice. In Papáček (ed.): Didaktika biologie České republice 2010 a badatelsky orientované vyučování. DiBi 2010. Sborník př́spěvki semináre, [online]. 25. a 26. března 2010, s. 145-162, Jihočeská univerzita, České Budějovice.

Samková, L. (2011). Badatelsky orientované vyučování matematiky.

Retrieved

from:http://home.pf.jcu.cz/ upvvm/2011/sbornik/clanky/36UPVM11Samkova.pdf

Bělská, L. (2014). Badatelsky orientované učení ve výuce př́rodopisu. České Budějovice, 2014. 62 1. Diplomová práce. Jihočeská univerzita v Českých Budějovicích. Vedoucí práce prof. RNDr. Miroslav Papáček, CSc.

Maňák, J. \& Švec, V. (2003). Výukové metody. Brno: Paido. 